\title{
Aerosol measurement methods to quantify spore emissions from fungi and cryptogamic covers in the Amazon
}

\author{
Nina Löbs ${ }^{1}$, Cybelli G. G. Barbosa ${ }^{1}$, Sebastian Brill ${ }^{1}$, David Walter ${ }^{1,2}$, Florian Ditas ${ }^{1}$, Marta de Oliveira Sá ${ }^{3}$, \\ Alessandro C. de Araújo ${ }^{4}$, Leonardo R. de Oliveira ${ }^{3}$, Ricardo H. M. Godoi ${ }^{5}$, Stefan Wolff ${ }^{1}$, Meike Piepenbring ${ }^{6}$, \\ Jürgen Kesselmeier $^{1}$, Paulo Artaxo ${ }^{7}$, Meinrat O. Andreae ${ }^{1,8}$, Ulrich Pöschl ${ }^{1}$, Christopher Pöhlker ${ }^{1}$, and \\ Bettina Weber ${ }^{1,9}$ \\ ${ }^{1}$ Multiphase Chemistry and Biogeochemistry Departments, Max Planck Institute for Chemistry, Mainz, 55128, Germany \\ ${ }^{2}$ Department of Biogeochemical Processes, Max Planck Institute for Biogeochemistry, Jena, 07701, Germany \\ ${ }^{3}$ Large-Scale Biosphere-Atmosphere Experiment in Amazonia (LBA), Instituto Nacional de Pesquisas \\ da Amazonia (INPA), Manaus-AM, CEP 69067-375, Brazil \\ ${ }^{4}$ Empresa Brasileira de Pesquisa Agropecuária (EMBRAPA), Belém-PA, CEP 66095-100, Brazil \\ ${ }^{5}$ Department of Environmental Engineering, Federal University of Paraná UFPR, Curitiba, PR, Brazil \\ ${ }^{6}$ Department of Mycology, Goethe University Frankfurt/Main, Frankfurt, 60438, Germany \\ ${ }^{7}$ Institute of Physics, University of São Paulo 05508-900, Brazil \\ ${ }^{8}$ Scripps Institution of Oceanography, University of California San Diego, La Jolla, CA 92037, USA \\ ${ }^{9}$ Institute of Plant Sciences, University of Graz, Holteigasse 6, 8010 Graz, Austria
}

Correspondence: Nina Löbs (n.loebs@mpic.de), Christopher Pöhlker (c.pohlker@mpic.de), and Bettina Weber (b.weber@mpic.de)

Received: 11 June 2019 - Discussion started: 13 August 2019

Revised: 20 November 2019 - Accepted: 25 November 2019 - Published: 15 January 2020

\begin{abstract}
Bioaerosols are considered to play a relevant role in atmospheric processes, but their sources, properties, and spatiotemporal distribution in the atmosphere are not yet well characterized. In the Amazon Basin, primary biological aerosol particles (PBAPs) account for a large fraction of coarse particulate matter, and fungal spores are among the most abundant PBAPs in this area as well as in other vegetated continental regions. Furthermore, PBAPs could also be important ice nuclei in Amazonia. Measurement data on the release of fungal spores under natural conditions, however, are sparse. Here we present an experimental approach to analyze and quantify the spore release from fungi and other spore-producing organisms under natural and laboratory conditions. For measurements under natural conditions, the samples were kept in their natural environment and a setup was developed to estimate the spore release numbers and sizes as well as the microclimatic factors temperature and air humidity in parallel to the mesoclimatic parameters net radiation, rain, and fog occurrence. For experiments in the laboratory, we developed a cuvette to assess the particle size and num-
\end{abstract}

ber of newly released fungal spores under controlled conditions, simultaneously measuring temperature and relative humidity inside the cuvette. Both approaches were combined with bioaerosol sampling techniques to characterize the released particles using microscopic methods. For fruiting bodies of the basidiomycetous species, Rigidoporus microporus, the model species for which these techniques were tested, the highest frequency of spore release occurred in the range from $62 \%$ to $96 \%$ relative humidity. The results obtained for this model species reveal characteristic spore release patterns linked to environmental or experimental conditions, indicating that the moisture status of the sample may be a regulating factor, whereas temperature and light seem to play a minor role for this species. The presented approach enables systematic studies aimed at the quantification and validation of spore emission rates and inventories, which can be applied to a regional mapping of cryptogamic organisms under given environmental conditions. 


\section{Introduction}

Particles released from the biosphere into the atmosphere are called primary biological aerosol particles (PBAPs). They comprise biogenic matter such as pollen, bacteria, viruses, spores of fungi, bryophytes and ferns, and cells and cell compounds (e.g., proteins) of plants and animals (Andreae and Crutzen, 1997; Després et al., 2012; Fröhlich-Nowoisky et al., 2016; Simoneit, 1977, 1989). They can influence the water cycle by acting as cloud condensation or ice nuclei, thereby triggering precipitation (Möhler et al., 2007; Pöschl et al., 2010), and they can affect the radiative budget of the atmosphere, via the absorption and scattering of radiation, on a local and global scale (Cox, 1995).

Although the general knowledge on PBAPs is still sparse, there are several studies on the sampling and sizing of PBAPs in the Amazon (Elbert et al., 2007; Gilbert and Reynolds, 2005; Graham et al., 2003; Huffman et al., 2012; MoranZuloaga et al., 2018; Pöschl et al., 2010; Whitehead et al., 2016; Womack et al., 2015). However, a large variety of techniques have been utilized in these aerosol sampling studies, which handicaps their direct comparability. For online counting and/or sizing of aerosols at different heights within and above of the canopy, the sensitive analyzers are mostly situated in weather-protected containers at the forest floor. The required long inlet lines from a tower or mast cause a preferential loss of larger particles (Huffman et al., 2012; Moran-Zuloaga et al., 2018; Pöschl et al., 2010). Other aerosol collection devices (e.g., impinger samplers) can be located at the desired sampling height without extended inlet lines (Elbert et al., 2007; Gilbert and Reynolds, 2005; Graham et al., 2003; Womack et al., 2015). The majority of these studies focuses on the aerosol or spore concentration in the atmosphere. However, the emission patterns of the source organisms, i.e., the spore release characteristics depending on climatic conditions and the physiological activity status, might also be relevant to explain the atmospheric concentrations (Šantl-Temkiv et al., 2019). To fill that gap, a setup focused on the aerosol release patterns and mechanisms of the organisms could generate new insights into the relevance of local bioaerosol emissions.

The Amazon Basin represents the world's largest rain forest, with a dimension of about $6000000 \mathrm{~km}^{2}$ (Melack and Hess, 2010). As tropical rain forests host an extensive spectrum of species and have an extremely high biomass turnover, bioaerosol transport from the biosphere into the atmosphere is high (Artaxo et al., 2013; Artaxo and Hansson, 1995; Crutzen et al., 1985; Simoneit et al., 1990). PBAPs have been said to account for a major fraction of coarse-mode aerosols in the Amazon (Elbert et al., 2012; Moran-Zuloaga et al., 2018; Pöschl et al., 2010; Whitehead et al., 2016), and fungal spores have been suggested to be a key component in the coarse-particle fraction (Elbert et al., 2007; Graham et al., 2003; Huffman et al., 2012; Sesartic et al., 2013).
Cryptogams, including lichenized and non-lichenized fungi, bryophytes, and ferns cover the surfaces of up to $100 \%$ of plants in tropical rain forests. They can be expected to play a major role in bioaerosol emissions, as they release reproductive units as a result of sexual or asexual reproduction (Elbert et al., 2007; Fröhlich-Nowoisky et al., 2016; Fürnkranz et al., 2008; Richards, 1954). Cryptogamic organisms are mostly of poikilohydric nature, meaning that they are unable to actively regulate their water content, which causes their moisture content to strongly depend on the environmental humidity conditions. Accordingly, under dry conditions the organisms are metabolically inactive until they are reactivated by moisture uptake.

Fungi represent a separate kingdom, with taxa being present in all types of natural environments. Within the kingdom, Ascomycota and Basidiomycota are the largest (Mueller et al., 2004; Neves et al., 2013) in addition to several smaller phyla. Microfungi, such as molds, develop spores directly from hyphae, whereas other fungi colonize their substrate (e.g., dead wood or soil) using vegetative hyphae and form fruiting bodies of varying sizes for spore production and liberation. A single large fruiting body may release millions of spores in order to succeed in dispersal, multiplication, and reproduction (Webster and Weber, 2007). The reproduction units of fungi comprise spores resulting from sexual (e.g., basidiospores and ascospores) and asexual modes of reproduction, such as teliospores, conidia, budding (yeast) cells, and fragments of hyphae (Cannon et al., 2018). Fungal spores in the atmosphere have been reported to reach number concentrations of $10^{4}$ to $10^{5} \mathrm{~m}^{-3}$ in the Amazon (Elbert et al., 2007; Graham et al., 2003; Hoose et al., 2010). On a global scale, fungal spores may account for 8 to $186 \mathrm{Tg} \mathrm{yr}^{-1}$ of bioaerosol emissions, which is roughly $23 \%$ of the total primary organic aerosol emission (Fröhlich-Nowoisky et al., 2016; Graham et al., 2003; Heald and Spracklen, 2009; Jacobson and Streets, 2009; Sesartic et al., 2013).

Species of Polyporales (Basidiomycota), the order of the model species of the present study, mostly colonize dead wood, where they form vegetative hyphae that degrade the wood. On the surface of dead wood they form fruiting bodies with pores located on their lower side. The surface of these pores is covered by a hymenium, where basidiospores are produced on basidia. Each basidium externally forms mostly four asymmetrical basidiospores on little curved, tapering stalks, called sterigmata. The spores are fixed to the sterigmata at the hilum, which therefore forms a characteristic feature of basidiospores.

In most terrestrial basidiomycetes the basidiospores are actively projected, thus the use of the term "ballistospores", and several ejection mechanisms have been suggested (Webster and Weber, 2007). A widely accepted mechanism is that of surface tension catapult, originally described by Buller (1922) and Ingold (1939). For activation, a drop of water, the Buller's drop, forms at the hilar appendix and a second shallower liquid deposit forms on the surface of the spore above 


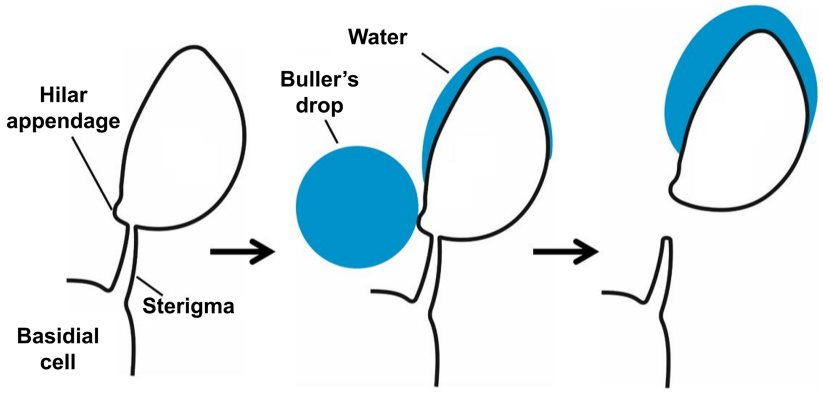

Figure 1. Schematic drawing of the spore-building parts of a basidiomycetous fungus. Active release mechanism based on a change of the gravity center due to the "Buller's drop" effect. Not to scale. Based on Piepenbring (2015).

the hilar appendix (Fig. 1). Both drops grow until they coalesce and then the basidiospore is immediately discharged (Pringle et al., 2005). This coalescence causes a sudden redistribution of mass and carries the spore and drop away from the sterigma. Experiments with the fungus Itersonilia sp. suggest that the liquid in both drops originates from water condensation upon the extrusion of a hygroscopic substance, e.g., mannitol and in some cases glucose. The spores measured were released from the sterigma at velocities above $1 \mathrm{~m} \mathrm{~s}^{-1}$, but at low wind velocities there was a quick deceleration and loss of velocity (Webster and Weber, 2007). Basidiospore sizes range between 3 and $20 \mu \mathrm{m}$ (Webster and Weber, 2007). In accordance with Buller (1922) the number of basidiospores produced by a single fruiting body can be extremely large, as, for example, one cap of the mushroom Agaricus campestris has been calculated to produce $\sim 2.6 \times 10^{9}$ spores over the course of $1 \mathrm{~d}$.

Water availability is a triggering factor for the formation of macroscopic fruiting bodies, where the spores are formed. Other parameters such as light, humidity, and temperature can influence spore liberation, and the simultaneous measurement of these parameters under natural and controlled conditions is needed to elucidate the relevant interrelations (Neves et al., 2013).

The aim of this study was to establish measurement techniques that allow a qualitative and quantitative assessment of spore emission patterns of non-lichenized fungi, lichens, bryophytes, and ferns under natural field conditions and under controlled environmental conditions in the lab. Measurements under field conditions allow spore release patterns to be followed over longer time spans, during diel cycles, and under changing environmental conditions, whereas lab measurements facilitate a controlled analysis of the effect of particular environmental parameters and a detailed quantification of spore emissions. Direct observations of PBAP emission patterns will help to better understand spatiotemporal patterns in the abundance of the Amazonian coarse-mode aerosol population.

\section{Materials and methods}

\subsection{Study site}

The experiments were conducted at the Amazon Tall Tower Observatory (ATTO) site in the central Amazon Basin, about $150 \mathrm{~km}$ northeast of the city of Manaus (Andreae et al., 2015). The trees of this plateau forest have an average height of $21 \mathrm{~m}$ and grow at a density of up to 600 trees ha $^{-1}$. With approximately 16000 estimated tree species, the Amazon has a high species diversity compared with other forest types (McWilliam et al., 1993; ter Steege et al., 2013). Precipitation has a seasonal minimum of around $47 \mathrm{~mm}$ per month in the dry season (August-November) and a maximum of $335 \mathrm{~mm}$ per month in the wet season (FebruaryMay), according to measurements conducted from 1961 to 1990 (Andreae et al., 2015). Further relevant details on the research site can be found in previous publications (Andreae et al., 2015; Pöhlker et al., 2019).

\subsection{Study organisms}

The investigated model species was collected in the plateau forest area of the ATTO site during the dry season in August 2018. For the measurements under field and laboratory conditions, two specimens of the same species, growing in close vicinity to each other, were used for parallel measurements. According to the macro-morphological characteristics of the sampled specimen, the basidioma was classified as a polyporoid fungus (Fig. 2). Combined with micro-morphological details of the hymenium and basidiospores, the species was identified as Rigidoporus microporus (Polyporales, Basidiomycota), which has already been reported for the Amazon area (Gomes-Silva et al., 2014). In the results section, the exemplary measurements made with the model species are presented. Due to the exemplary nature of the data, replicate measurements have not been conducted here, but will be needed during an analysis of the emission patterns of different organisms.

\subsection{Measurements under natural conditions}

In a first approach, bioaerosol emission patterns were investigated with a mobile measurement setup directly at selected organisms in the field. The setup is illustrated in Fig. 3. For particle counting and sizing, an optical particle sizer (OPS model 3330, size range: 0.3 to $10 \mu \mathrm{m}$; TSI Inc., Shoreview, Minnesota, USA), was operated at a sampling interval of $30 \mathrm{~s}$ with an air flow of $1 \mathrm{~L} \mathrm{~min}^{-1}$. This instrument classifies the detected particles based on aerosol light scattering into 16 size bins ranging from 0.3 to $10 \mu \mathrm{m}$. The OPS was characterized in more detail in Moran-Zuloaga et al. (2018). At the OPS inlet, an antistatic tube (inner diameter of $4 \mathrm{~mm}$, length of $\sim 1 \mathrm{~m}$; conductive tubing, TSI Inc., Minnesota, USA) extended by a plastic funnel (diameter of $8 \mathrm{~cm}$, Carl Roth GmbH Co, Karlsruhe, Germany) was installed. The funnel 

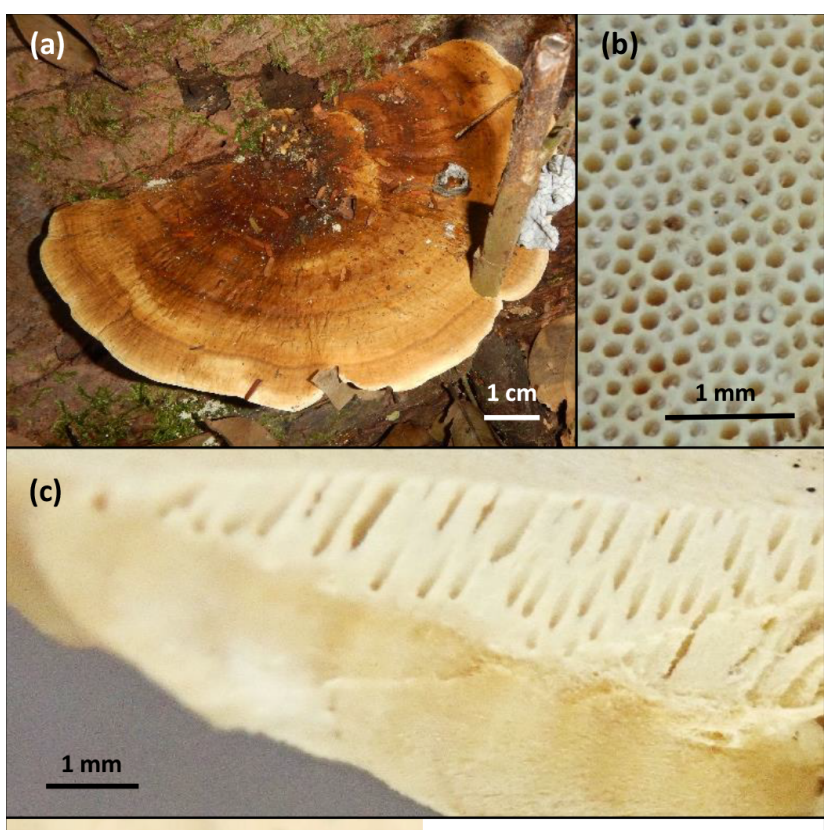

(d)

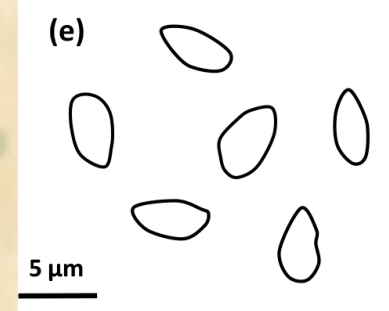

Figure 2. Photographic documentation of the measured basidiomycete Rigidoporus microporus. (a) Sessile basidioma growing on a dead hardwood, (b) polyporoid hymenium with white surface, (c) vertical cross-section of hymenium with homogeneous content, (d) microscopic image of the one-celled colorless spores at $1000 \times$ magnification, and (e) schematic drawing of some of the observed spores, average size $3 \mu \mathrm{m} \times 5 \mu \mathrm{m}$. Scales indicated.

was placed 2 to $5 \mathrm{~cm}$ from the investigated emission source (Fig. 3c). The measured particle concentrations were averaged over $5 \mathrm{~min}$. For the fine and coarse mode, the particles in the size range from 0.3 to $1 \mu \mathrm{m}$ and 1 to $10 \mu \mathrm{m}$, respectively, were summed and averaged over $5 \mathrm{~min}$ intervals. The OPS instrument has a filter, where the sampled particles are collected. These filters cannot be directly used for microscopy, but the particles can be transferred to microscopy slides and subsequently analyzed by light microscopy and compared to imagery obtained from sections of the fungal hymenium, as shown in Fig. 2d.

Air temperature and relative humidity $(\mathrm{RH})$ were measured at $30 \mathrm{~s}$ intervals at a distance of approximately 5 to $10 \mathrm{~cm}$ from the emission source (temperature/relative humidity data logger, HOBO U23 v2, Onset, Bourne, Massachusetts, USA; Fig. 3c). For weather protection, the instruments were installed in a metal housing $(55 \mathrm{~cm} \times 48 \mathrm{~cm} \times$ $48 \mathrm{~cm}$, Zarges GmbH, Weilheim, Germany; Fig. 3b). Thus,
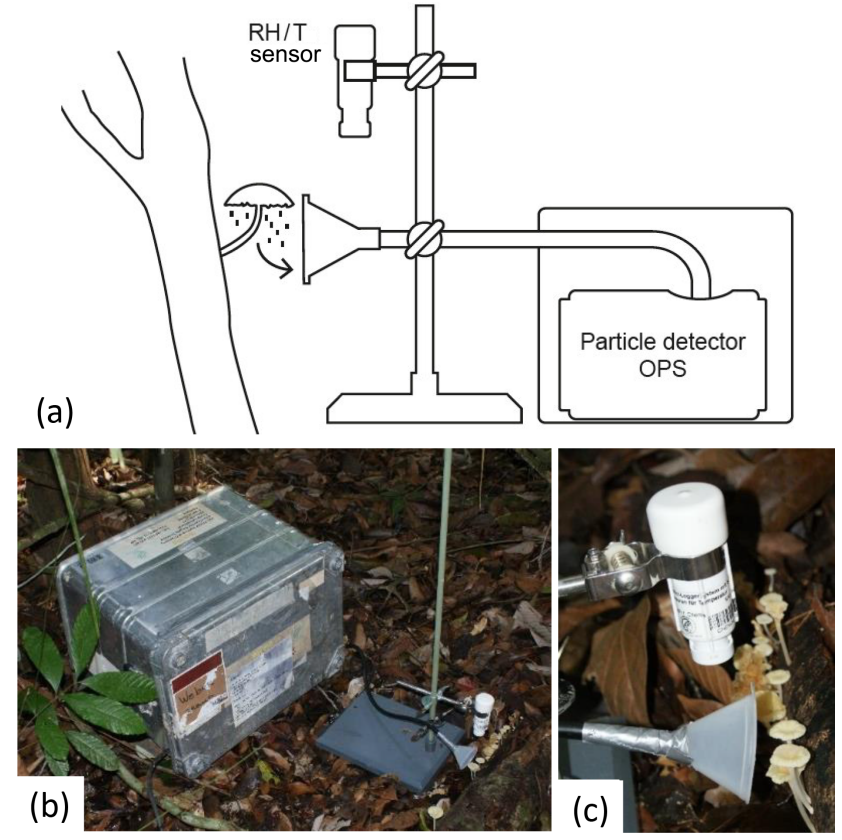

Figure 3. Setup used for field measurements. The optical particle sensor (OPS) is located in a box for weather protection. From this, an inlet ending with a funnel leads to the organism of interest. The setup is accompanied by a temperature and humidity (RH/T) sensor located in the direct vicinity of the sample. (a) Schematic drawing, (b) overview photograph, and (c) close-up photograph of the described setup.

only the inlet and the sensor tip were placed outside the box, next to the investigated organism. The measurements were performed over $24 \mathrm{~h}$.

As accessory data on the mesoclimate, net radiation (in watts per square meter, $\mathrm{W} \mathrm{m}^{-2}$ ) was measured at a height of $75 \mathrm{~m}$ (net radiometer, NR-LITE2, Kipp \& Zonen, Netherlands), precipitation (in millimeters per minute, $\mathrm{mm} \mathrm{min}^{-1}$ ) at a height of $81 \mathrm{~m}$ (rain gauge TB4, Hydrological Services Pty. Ltd., Australia), and the occurrence of fog was detected with visibility measurements using an optical fog sensor installed at a height of $43 \mathrm{~m}$ (OFS, Eigenbrodt GmbH, Königsmoor, Germany). Fog events were defined as occurring at visibility values below $2000 \mathrm{~m}$. Data loggers recorded the data at $1 \mathrm{~min}$ intervals (CR3000 and CR1000, Campbell Scientific, Logan, Utah, USA; Andreae et al., 2015). Based on the field data, 5 min averages have been generated.

The time is presented in local time (LT), which is UTC-4 (UTC represents coordinated universal time).

\subsection{Cuvette system for laboratory experiments}

Measurements in the lab are used to verify the field data and to characterize the spore release patterns over a wider range of environmental conditions. For experiments under controlled laboratory conditions, we developed a cuvette system where the sample is placed in the air stream. With respect 

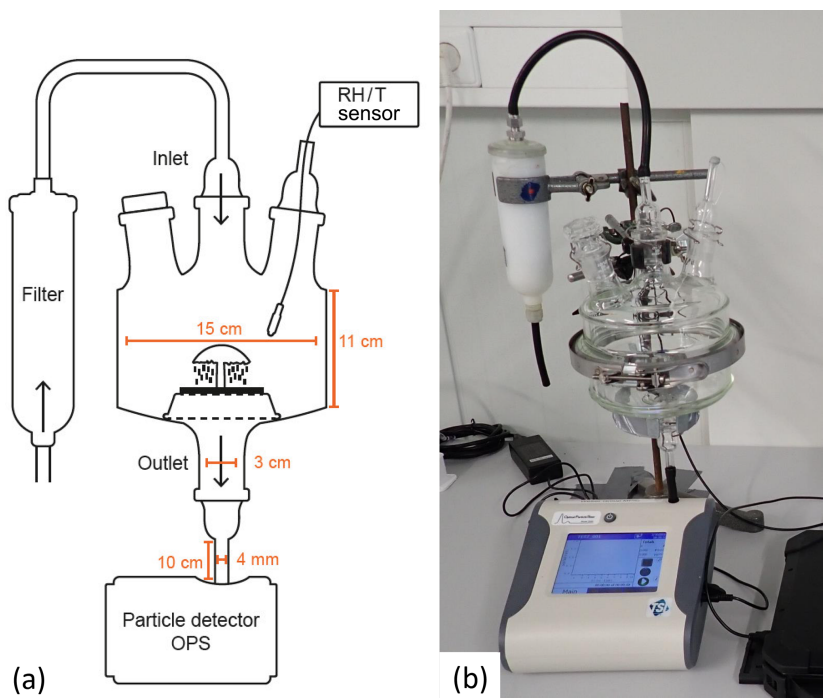

Figure 4. Setup used for laboratory experiments. The samples are placed in a glass cuvette in a vertical air stream. Air is supplied via an inlet with a filter connected to it; the outlet is connected to an OPS for particle measurements. A temperature and humidity $(\mathrm{RH} / T)$ sensor is placed inside the cuvette via an opening in the upper lid, which is sealed to avoid contamination. (a) Schematic drawing, and (b) close-up photograph.

to the cuvette, a glass chamber was built from two horizontally arranged flat flange clear glass units (inner diameter of $15 \mathrm{~cm}$, total inner height of $11 \mathrm{~cm}$; Fig. 4), the upper unit had three openings and the lower unit had one opening. The openings of the upper lid were connected to an inlet tube that provided outside air via a filter (pore diameter of $0.3 \mu \mathrm{m}$, HEPA filter capsule, Pall, Dreieich, Germany) and to a sensor measuring RH and temperature inside the chamber (MSR 145 data logger, Seuzach, Switzerland). A third opening for further manipulations or measurements was closed with a glass stopper, as it was not in use. The opening of the lower lid was connected to an OPS (OPS 3330, TSI Inc. Shoreview, Minnesota, USA) via a conductive tube with a length of approximately $10 \mathrm{~cm}$ (inner diameter of $4 \mathrm{~mm}$, conductive tubing, TSI Inc., Minnesota, USA). Inside the cuvette, the sample was placed on an aluminum grid, which allowed the emitted particles to drop into the outlet tube to be measured.

Measurements were performed over the course of $24 \mathrm{~h}$ at a sampling interval of $10 \mathrm{~s}$ and an air flow of $1 \mathrm{~L} \mathrm{~min}^{-1}$. Records obtained with an empty cuvette, which showed low particle numbers indicating an air-tight measurement setup and an undisturbed measurement signal, were used as blank/background signal. In a next step, a sample was placed inside the cuvette and investigated under natural moisture conditions, i.e., with the water content it had directly after field collection. In a third step, the sample was removed from the cuvette, sprayed with water until the outside of the sample was glossy wet and inserted into the cuvette again. In a final step the blank cuvette was measured again. While steps 1 and 4 lasted for approximately 1 to $5 \mathrm{~h}$ each, step 2 was run for roughly $4 \mathrm{~h}$ and step 3 was run for about $17 \mathrm{~h}$. As the opening of the cuvette caused a short but strong increase in particles across all detected bins, these peaks were removed prior to further analysis of the data. In the example presented only the initial blank is shown, as the final blank showed identical low values, thus demonstrating reproducibility.

The water content (WC) of the samples was determined gravimetrically as a percentage value based on the dry weight (\% DW), determined after the measurements upon drying in an oven at $60^{\circ} \mathrm{C}$ until weight constancy was reached. Moreover, during lab measurements, the filter of the OPS could be used for microscopic analyses as described in Sect. 2.3.

\subsection{Particle collection and microscopic analysis}

A custom-made impactor was used to collect samples of the released particles for later microscopic or chemical analysis. With respect to the impactor, a customized metallic capsule with plastic support for the sampling substrate was used, where round microscopy cover slides with a diameter of $12 \mathrm{~mm}$ were inserted as collection substrate. The impactor was connected to the laboratory experiment chamber via the tubing at the inlet of the lower lid, with a pump (M42x30/I, KAG, Hannover, Germany; flow rate of $8 \mathrm{~L} \mathrm{~min}^{-1}$ ) following the impactor. Particle collection with the impactor was conducted for different periods (ranging between $5 \mathrm{~s}$ and $1 \mathrm{~min}$ ) depending on the sample and its spore release behavior. For Rigidoporus microporus, the particle collection was carried out for $30 \mathrm{~s}$. From each investigated organism three slides were collected one after the other. The sample slides were stored in flat containers (Analyslide Petri dishes, Polystyrol, 47 mm, Pall Life, Ann Arbor, Michigan, USA) under dry conditions at room temperature $\left(\sim 25^{\circ} \mathrm{C}\right)$ until further investigations were carried out.

For microscopic observation of the collected spores, each round cover slide was mounted onto a clear glass microscopy slide $(26 \mathrm{~mm} \times 76 \mathrm{~mm}$, pre-cleaned, ready to use, Gerhard Menzel, Braunschweig, Germany). The optical analysis was carried out with a light microscope using magnifications of $400 \times$ and $1000 \times$ (Primo Star, Carl-Zeiss Microscopy, Jena, Germany). The images were captured with a coupled camera (Axiocam 105 color, Carl-Zeiss Microscopy, Jena, Germany) and processed using the manufacturer's software (ZEN software, 2.3 edition, Carl-Zeiss Microscopy, Jena, Germany).

\subsection{Data and statistical analysis}

IGOR Pro software (Igor Pro 6.3.7, WaveMetrics. Inc, Lake Oswego, Oregon, USA) was used to calculate the $5 \mathrm{~min}$ averages and help with the graphical analysis.

Statistica software (13.3, StatSoft.Inc., Tulsa, Oklahoma, USA) was applied to test the normal distribution and the variability of the particle concentrations during the different steps of the laboratory experiment. A chi-square test was 
applied to test the normal distribution of the data, and a Kruskal-Wallis test was used to test the difference between the blank cuvette, the naturally moist, and the artificially moistened sample. We applied a two-sided significance level of $p=0.05$.

\section{Initial results and discussion}

\subsection{Measurements under natural conditions}

The following paragraph presents the first results obtained from measurements of spore release patterns of one exemplary organism in the field, which illustrates the potential of this approach to explore the link between bioaerosol release and micrometeorological parameters in a systematic way.

During measurements of the model species under ambient conditions, neither fog nor rain occurred (Fig. 5). The coarsemode particles (Fig. 5b) exhibited the highest concentrations during nighttime, when the RH ranged from $73 \%$ to $96 \%$, with peak concentrations of $N_{1-10}=600 \mathrm{~cm}^{-3}$, whereas the lowest numbers were measured during the day with only $\sim 0.8 \mathrm{~cm}^{-3}$ at RH values between $66 \%$ and $85 \%$. On average, coarse-mode particle concentrations were $N_{1-10}=$ $330 \pm 105 \mathrm{~cm}^{-3}$ during nighttime (from 18:00 to 06:00 LT) and $N_{1-10}=90 \pm 102 \mathrm{~cm}^{-3}$ during the day. Pronounced diurnal cycles of coarse-mode particle abundance in the Amazon, such as the cycle found here (Fig. 5), have been described in previous studies (Huffman et al., 2012; MoranZuloaga et al., 2018). These diurnal patterns might be driven by spore emission patterns, boundary layer dynamics (daytime dilution vs. nighttime concentration), or a combination of both. During convective daytime hours, the boundary layer top is located much higher than during nighttime, which results in a dilution of the local emissions during the day and elevated concentrations during the night (Neves and Fisch, 2015). However, in our case the most important driver for the diurnal pattern of the coarse-mode particles might be the release pattern of the fungus, as the measuring device was located in close vicinity to the releasing fungus. Note in this context that the coarse-mode background concentration at the ATTO site ranges well below $N_{1-10}=5 \mathrm{~cm}^{-3}$ for most of the year (Moran-Zuloaga et al., 2018). Thus, the number concentrations obtained directly at the fungus were significantly higher and cannot be explained by variations in the background concentration. Coarse-mode particle occurrence in the open atmosphere is likely caused by a combination of particle release patterns and boundary layer height effects.

In contrast to the coarse-mode diurnal patterns, the fine-mode concentrations were much lower, with the highest fine-mode concentration reached during the day $\left(N_{0.3-1}=74 \mathrm{~cm}^{-3}\right)$ and the lowest concentration during night $\left(N_{0.3-1}=50 \mathrm{~cm}^{-3}\right)$. On average, the particle concentration in the fine mode reached $N_{0.3-1}=64 \pm 9.2 \mathrm{~cm}^{-3}$ during the day and $N_{0.3-1}=58 \pm 3.2 \mathrm{~cm}^{-3}$ during the night.
Overall, the fine-mode and the coarse-mode particles show opposite diurnal trends, which indicates that both might be driven by different mechanisms. The fine-mode particle concentration $N_{0.3-1}$ probably originated from biomass burning events, as simultaneous online measurements with a multiangle absorption photometer (MAAP; Thermo Scientific, MA, USA) revealed elevated values of black carbon ranging be-

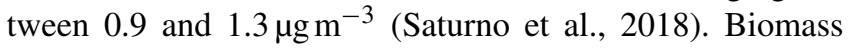
burning events generally occur at a higher frequency during the dry season compared with the wet season. The nighttime minimum in $N_{0.3-1}$ can be explained by dry deposition of the fine-mode aerosol to the forest canopy in the shallow nocturnal boundary layer.

The presented experimental approach of simultaneous observations of the particle size distribution, $\mathrm{RH}$, temperature, and net radiation close to the organism allows for the relation of the organism's spore emission patterns to meteorological parameters. Based on a larger number of measurements from multiple organisms, which is the subject of ongoing work, this is intended to provide a dataset of predictive values with regard to bioaerosol release and abundance. For further measurements, a combination of emission monitoring with a wider range of meteorological data should provide valuable insights into the detailed spore emission patterns. As the geometric size of the spores of Rigidoporus microporus ranges between 3 and $5 \mu \mathrm{m}$ (Gomes-Silva et al., 2014), they are expected to be measured in the coarse-mode fraction. Upon an increase in RH in connection with a decrease in net radiation and temperature in the evening hours, the spore concentrations emitted by this sample increased immediately (Fig. 5). In contrast to this, spore concentrations decreased in the morning; this decrease was simultaneous to a decrease in the RH and an increase in the net radiation and temperature. Elevated basidiospore concentrations during nighttime hours have previously been observed and were linked to the ballistic spore emission mechanism described above (Webster and Weber, 2007).

Rain and fog may also play an important role in modulating the bioaerosol release patterns (Huffman et al., 2013; Schumacher et al., 2013). Due to the absence of rain and fog during the time frame shown in Fig. 5, the relevance of these parameters on the spore release cannot be investigated in this particular case. Nevertheless, we believe that these parameters could give valuable insights into particle release patterns and processes in other cases, which is also subject of ongoing work. The results presented have to be considered as exemplary and do not allow for generalizations, as different emission patterns and relevant environmental parameters can be expected for different species, but they demonstrate the practicability of the measurement techniques.

\subsection{Laboratory experiments}

Measurements under laboratory conditions allowed for a detailed investigation of the particle emission properties of a 


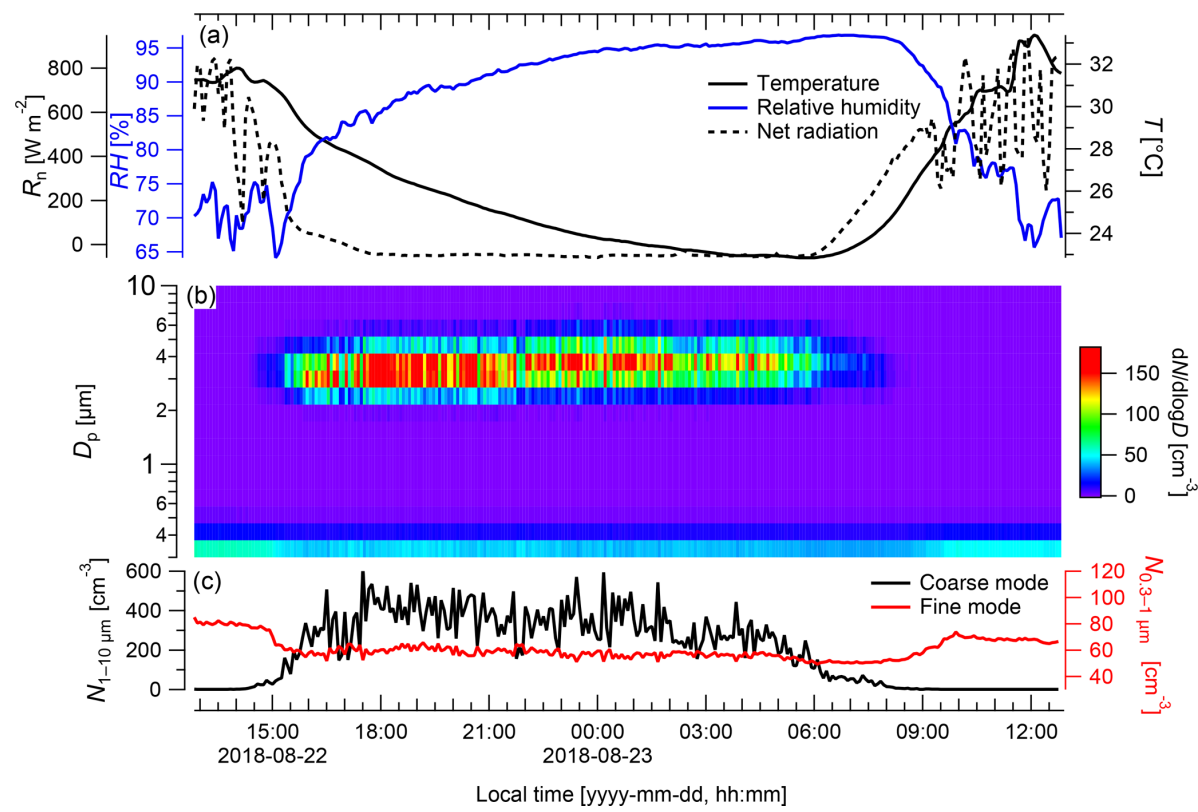

Figure 5. Particle emission patterns of Rigidoporus microporus measured under field conditions over the course of $24 \mathrm{~h}$. (a) Temperature (T) and relative humidity $(\mathrm{RH})$ measured next to the sample organism and net radiation $\left(R_{\mathrm{n}}\right)$ measured at a height of $75 \mathrm{~m}$, (b) concentration of different particle size classes over time, and (c) the number of particles ranging from 0.3 to $1 \mu \mathrm{m}$ (fine mode) and from 1 to $10 \mu \mathrm{m}$ diameter (coarse mode). Data are presented as 5 min averages.

specific organism under controlled conditions, due to the exclusion of the surrounding emission sources. In combination with field measurements of the same specimen, the particle release process of the study organism can be separated from the environmental processes.

During the laboratory experiment, the initial blank showed average coarse- and fine-mode particle concentrations close to zero (both $<0.001 \mathrm{~cm}^{-3}$, respectively; Fig. 6). In the coarse mode, the highest average particle concentrations were detected for the naturally moistened sample $\left(N_{1-10}=\right.$ $\left.10 \mathrm{~cm}^{-3}\right)$ and the artificially moistened sample $\left(N_{1-10}=\right.$ $\left.2.2 \mathrm{~cm}^{-3}\right)$, which were significantly higher than the blank $\left(N_{1-10}<0.001 \mathrm{~cm}^{-3} ; p<0.001\right)$. The coarse-mode particle concentrations showed defined pulses when the sample was in the cuvette. Right after installation of the naturally moist sample in the cuvette, a defined peak spanning over approximately $2 \mathrm{~h}$ occurred, reaching a maximum particle concentration of $N_{1-10}=20 \mathrm{~cm}^{-3}$. The WC of the sample ranged from $190 \%$ to $170 \%$ and the RH ranged from $66 \%$ to $64 \%$ during this time span. After the installation of the artificially moistened sample there were two defined, but somewhat smaller, pulses, although these pulses still reached maximum concentrations of $N_{1-10}=13$ and $\mathrm{N}_{1-10}=9.4 \mathrm{~cm}^{-3}$ in the coarse mode, respectively. They had a duration of approximately 1.5 and $2 \mathrm{~h}$, and during these times WC values ranged from $244 \%$ to $226 \%$ and $197 \%$ to $169 \%$, and RH ranged from $67 \%$ to $65 \%$ and $63 \%$ to $62 \%$, respectively. The lowest particle concentration of $N_{1-10}<0.001 \mathrm{~cm}^{-3}$, which is very close to zero, was measured from 06:00 to
11:00 LT, while the WC ranged from $83 \%$ to $148 \%$ and the $\mathrm{RH}$ ranged from $52 \%$ to $59 \%$.

In the fine mode, particle concentrations throughout the experiment were very low (i.e., $N_{0.3-1}<0.001 \mathrm{~cm}^{-3}$ ), which indicated the absence of leaks in the system and further suggested that no fine-mode particles were co-emitted with the coarse-mode pulses.

\subsection{Particle collection}

On the impactor samples, the particles were concentrated in one spot surrounding the impaction center. The number of particles varied according to the sampling time and bioaerosol emission by the respective sample. Using the microscope at a magnification of at least $400 x$, it was possible to visualize the collected spores. For the species examined, we microscopically observed subglobose spores, about $3 \mu \mathrm{m} \times 5 \mu \mathrm{m}$ in size, besides other random particles from the organism, e.g., fragments of hyphae about 1 to $8 \mu \mathrm{m}$ in length, and undefined particles in smaller concentrations, ranging from 0.5 to $10 \mu \mathrm{m}$ in size.

Impactor studies may also be useful during field measurements, as the coarse-mode particles could be collected with the field setup. Another option would be to use a new filter in the OPS and to investigate the spores collected on the filter by means of microscopy after sampling. In our field measurements, the contamination from surrounding emission sources was kept as small as possible by installing the inlet funnel of the detector close to the organism of interest. 


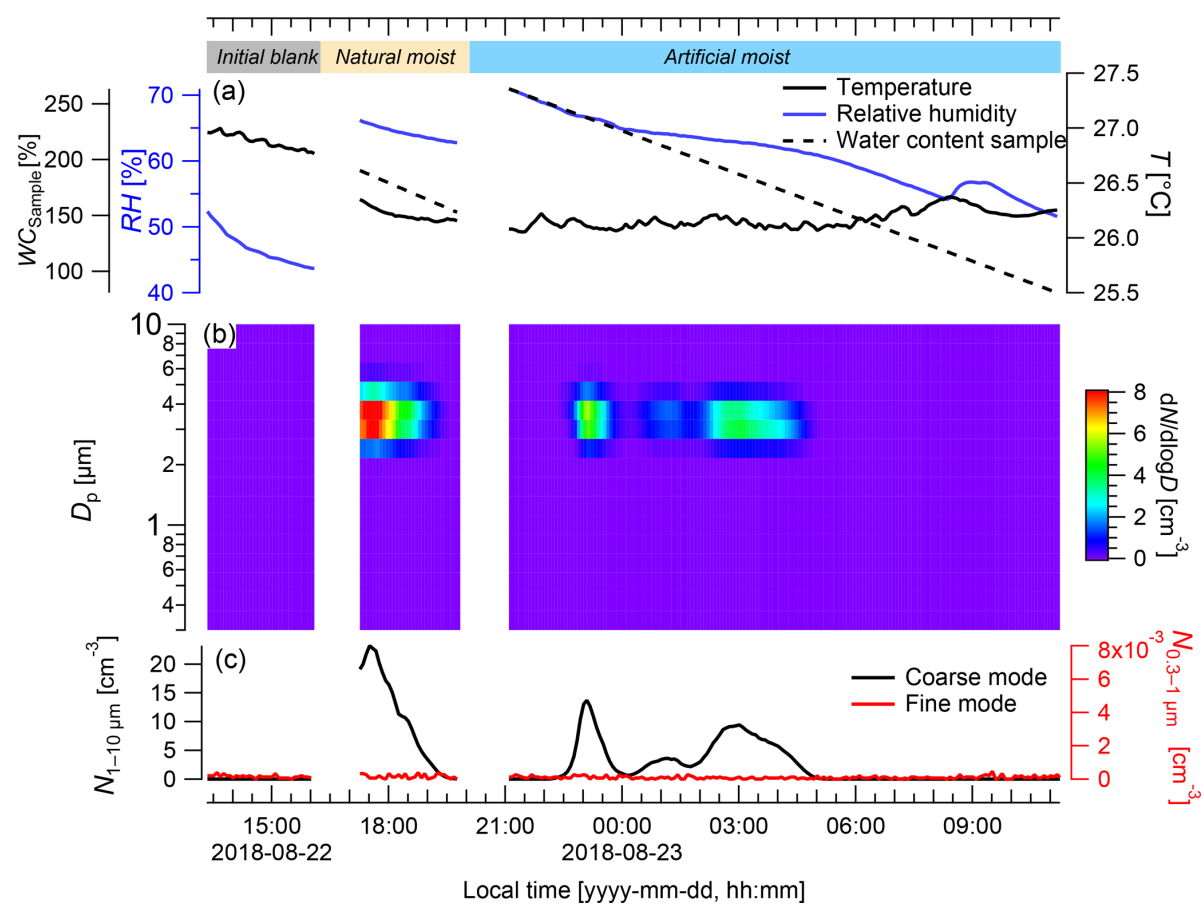

Figure 6. Particle emission patterns of Rigidoporus microporus measured under lab conditions. (a) Temperature ( $T$ ) and relative humidity (RH) measured inside the cuvette, and the gravimetrically determined water content of the sample $\left(\mathrm{WC}_{\text {sample }}\right.$ ); (b) the concentration of different particle size classes over time; and (c) the number of the particles ranging from 0.3 to $1 \mu \mathrm{m}$ (fine mode) and from 1 to $10 \mu \mathrm{m}$ in diameter (coarse mode). In the beginning and at the end of the measurement, a blank measurement was conducted with an empty cuvette (see labeling in panel (a); final blank not shown for brevity). After the initial blank, the sample was first measured with its natural water content (natural moisture) and then after spraying with water (artificial moisture). When the cuvette was opened for the insertion and removal of the sample, particles from outside caused a short increase in particles (measurement artifact), which was removed. Data are presented as 5 min averages.

Collecting the released material with an impactor during the laboratory experiment minimizes contamination from other sources and allows for a detailed observation of the particles (spores, cell fractions, etc.) released by the investigated organism. Additionally, the collected material can be used for a chemical characterization of the observed particles by analyzing molecular markers, like sugar alcohols (e.g., arabitol and mannitol), sterols (e.g., ergosterol), and others, as well as an assessment of the total protein content.

\subsection{Overall discussion}

The combined approach of field and the laboratory measurements seems to be very promising for investigations of the spore release patterns of spore-producing organisms and their relevance for atmospheric spore concentrations. While field measurements are used to analyze the spore emission patterns of the investigated organisms under natural environmental conditions, lab measurements facilitate analyses under controlled conditions over a wide range of environmental characteristics. Thus, this combined approach allows for a thorough characterization of the bioaerosol release patterns and mechanisms of defined organisms or communities.
Until now, bioaerosol measurement techniques have mainly been used to measure atmospheric concentrations of overall aerosols in the atmosphere. Some of them distinguished between aerosols of biotic and abiotic origin, but we are not aware of techniques that have been used to characterize the spore emission patterns of single organisms. Thus, the strength of our approach is that it allows for the characterization of the spore release patterns of single organisms or cryptogamic communities under defined environmental conditions in the field and in the lab.

Measurements inside the cuvette allowed for close control of the environmental parameters, e.g., the air circulation, temperature, humidity, and light. The measured particles covered a narrow size range $(2.5-4 \mu \mathrm{m}$ in diameter) in the coarse mode, which conforms to the spore size of the investigated fungus, whereas fine-mode particles seemed to be of minor importance. The highest numbers of basidiospores were emitted under naturally moist and artificially moistened conditions at water contents of the fungal fruiting body ranging from $244 \%$ to $169 \%$. Thus, the water content seems to play a relevant role in the spore emission process, which is in close agreement with other reports (Ehlert et al., 2017; Ingold, 1985; Sadyś et al., 2018) and with the fact that wa- 
ter condensation is essential for the active discharge of basidiospores. However, for this technique the fruiting bodies are mostly separated from their vegetative mycelium in the substrate (dead wood) that provides water, minerals, and nutrients for the fruiting body. This separation may affect the release of spores or other particles. For the empty cuvette, particle concentrations of less than $0.2 \mathrm{~cm}^{-3}$ were measured, indicating that the blanks serve as a good baseline for the laboratory measurements.

The measurements under field conditions showed a pronounced diurnal pattern in the coarse mode with the highest concentrations during nighttime, which has already been reported for other fungal species (Fernando et al., 2000; Gilbert and Reynolds, 2005; Stensvand et al., 1998). Aerosol and trace gas concentrations have frequently been shown to also display diurnal and seasonal patterns (Gadoury et al., 1998; Huffman et al., 2012; Moran-Zuloaga et al., 2018; Pöhlker et al., 2012; Yáñez-Serrano et al., 2015). However, in the natural environment there are many other emitting sources in the surrounding area, which might affect the measurement, and other environmental parameters, like the spectral composition of light (Ehlert et al., 2017; Igbalajobi et al., 2019; Pruß et al., 2014), might serve as particle release triggers; these factors have not been considered here. Other references have already indicated that $\mathrm{RH}$ or dew are triggering factors for spore release (Gosselin et al., 2016; Liang et al., 2013; Stensvand et al., 1998; Zhang et al., 2010). Overall, the spore release patterns can be expected to show both interspecific and intraspecific variability. The monitoring of a larger variety of organisms might help to characterize the dominating release pattern of organisms in the environment and to identify the triggering factors.

In earlier studies, a vertical structure of aerosols within the canopy was shown in the tropics (Gilbert and Reynolds, 2005), which could be investigated by utilizing this method to monitor the organisms at varying canopy heights. If the results of spore emission experiments are coupled with an inventory of cryptogams, very promising insights might be achieved. With both particle observation techniques, i.e., field and laboratory measurements, particles in the same size range have been sampled, confirming that the laboratory measurements can be considered as validation for the results obtained in the field. Additionally, the microscopic observation of the collected spores is fundamental for validation of the spore size and for identification of the organism being observed. Fine-mode particles were only sampled during the field experiment, indicating a different source for this particle fraction. An experimental approach of screening different spore-producing organisms at different canopy height levels and during different seasons might provide new insights into the relevance of spore-producing organisms for atmospheric aerosols and their effects on regional weather and climate.
Data availability. The data presented in the paper are provided in the Supplement.

Sample availability. Sample material of the investigated fungus can be loaned from the authors upon request.

Supplement. The supplement related to this article is available online at: https://doi.org/10.5194/amt-13-153-2020-supplement.

Author contributions. BW, NL, CP, SB, FD, and CGGB designed the experiments and SB, NL, and CGGB carried them out. CGGB and MP identified the fungus. MdOS, ACdA, and LRdO measured, analyzed, and supplied the climate data. RHMG, SW, JK, PA, MOA, and UP provided valuable input regarding the design and realization of on-site bioaerosol measurements. NL and DW performed the formal analysis. NL, BW, and CP prepared the paper with contributions from all co-authors. NL, CGGB, and SB contributed equally to this paper.

Competing interests. The authors declare that they have no conflict of interest.

Acknowledgements. We would like to acknowledge the German Federal Ministry of Education and Research (BMBF) and the Max Planck Society for supporting this project as well as the construction and operation of the ATTO site. We also acknowledge support from the Brazilian Ministério da Ciência, Tecnologia e Inovação (MCTI/FINEP) as well as the Amazon State University (UEA), FAPEAM, LBA/INPA, and SDS/CEUC/RDS-Uatumã for their support during the construction and operation of the ATTO site. We would like to thank Reiner Ditz, Susan Trumbore, Alberto Quesada, Thomas Disper, and Hermes Braga Xavier for technical, logistical, and scientific support within the ATTO project; and Thomas Klimach, Daniel Pickersgill, Isabella Hrabě de Angelis, Harald Paulsen, Peter Hoor, and Eckhard Thines for their technical and scientific expertise. Nina Löbs would like to thank the Max Planck Graduate Center (MPGC) for their support. Sebastian Brill, Cybelli G. G. Barbosa, David Walter, Florian Ditas, Stefan Wolff, Ulrich Pöschl, Christopher Pöhlker, and Bettina Weber appreciate the support from the Max Planck Society. Marta de Oliveira Sá and Leonardo R. de Oliveira would like to thank the Instituto Nacional de Pesquisas da Amazônia (INPA) for their support. Ricardo H. M. Godoi would like to thank the Federal University of Paraná. Paulo Artaxo would like to acknowledge funding from FAPESP (Fundação de Amparo à Pesquisa do Estado de São Paulo) and CNPq. Alessandro C. de Araújo would like to thank the Empresa Brasileira de Pesquisa Agropecuária (EMBRAPA). Meike Piepenbring would like to thank the Goethe University Frankfurt/Main. Meinrat O. Andreae appreciates the support from the Max Planck Society and the University of San Diego. Bettina Weber would like to thank the Karl-Franzens-Universität Graz. This paper contains the results of research conducted under the Technical/Scientific Cooperation Agreement between the National Institute for Amazonian Research, the State University of Amazonas, and the Max Planck 
Society. The opinions expressed are the entire responsibility of the authors and not of the participating institutions.

Financial support. This research has been supported by the German Federal Ministry of Education and Research (Bundesministerium für Bildung und Forschung, grant nos. 01LB1001A and 01LK1602B), the Brazilian Ministério da Ciência, Tecnologia e Inovação (MCTI/FINEP, grant no. 01.11.01248.00), the Max Planck Society (Max-Planck-Gesellschaft, grant no. M.IF.A.CHEM8095), and Fundação de Amparo à Pesquisa do Estado de São Paulo (FAPESP, grant no. 2017/17047-0) and CNPq (grant no. 425100/2016-2).

The article processing charges for this open-access publication were covered by the Max Planck Society.

Review statement. This paper was edited by Pierre Herckes and reviewed by four anonymous referees.

\section{References}

Andreae, M. O. and Crutzen, P. J.: Atmospheric Aerosols: Biogeochemical Sources and Role in Atmospheric Chemistry, Science, 276, 1052-1058, 1997.

Andreae, M. O., Acevedo, O. C., Araùjo, A., Artaxo, P., Barbosa, C. G. G., Barbosa, H. M. J., Brito, J., Carbone, S., Chi, X., Cintra, B. B. L., da Silva, N. F., Dias, N. L., Dias-Júnior, C. Q., Ditas, F., Ditz, R., Godoi, A. F. L., Godoi, R. H. M., Heimann, M., Hoffmann, T., Kesselmeier, J., Könemann, T., Krüger, M. L., Lavric, J. V., Manzi, A. O., Lopes, A. P., Martins, D. L., Mikhailov, E. F., Moran-Zuloaga, D., Nelson, B. W., Nölscher, A. C., Santos Nogueira, D., Piedade, M. T. F., Pöhlker, C., Pöschl, U., Quesada, C. A., Rizzo, L. V., Ro, C.-U., Ruckteschler, N., Sá, L. D. A., de Oliveira Sá, M., Sales, C. B., dos Santos, R. M. N., Saturno, J., Schöngart, J., Sörgel, M., de Souza, C. M., de Souza, R. A. F., Su, H., Targhetta, N., Tóta, J., Trebs, I., Trumbore, S., van Eijck, A., Walter, D., Wang, Z., Weber, B., Williams, J., Winderlich, J., Wittmann, F., Wolff, S., and Yáñez-Serrano, A. M.: The Amazon Tall Tower Observatory (ATTO): overview of pilot measurements on ecosystem ecology, meteorology, trace gases, and aerosols, Atmos. Chem. Phys., 15, 10723-10776, https://doi.org/10.5194/acp-15-10723-2015, 2015.

Artaxo, P. and Hansson, H.-C.: Size distribution of biogenic aerosol particles from the Amazon Basin, Atmos. Environ., 29, 393-402, 1995.

Artaxo, P., Rizzo, L. V., Brito, J. F., Barbosa, H. M. J., Arana, A., Sena, E. T., Cirino, G. G., Bastos, W., Martin, S. T., and Andreae, M. O.: Atmospheric aerosols in Amazonia and land use change: From natural biogenic to biomass burning conditions, Faraday Discuss., 165, 203-235, https://doi.org/10.1039/c3fd00052d, 2013.

Buller, A. H. R.: Researches on Fungi, Longmans Green \& Co., London, 1922.

Cannon, P., Aguirre-Hudson, B., Aime, M. C., Ainsworth, A. M., Bidartondo, M. I., Gaya, E., Hawksworth, D., Kirk, P., Leitch, I. J., and Lücking, P.: State of the world's fungi - Definition and diversity, Kew Royal Botanic Gardens, available at: https://stateoftheworldsfungi.org/2018/ definition-and-diversity.html (last access: 20 November 2019), 2018.

Cox, C. S.: Physical aspects of bioaerosol particles, in: Bioaerosol Handbook, chap. 3, 15-25, 1995.

Crutzen, P. J., Delany, A. C., Greenberg, J., Haagenson, P., Heidt, L., Lueb, R., Pollock, W., Seiler, W., Wartburg, A., and Zimmerman, P.: Tropospheric chemical composition measurements in Brazil during the dry season, J. Atmos. Chem., 2, 233-256, https://doi.org/10.1007/BF00051075, 1985.

Després, V. R., Alex Huffman, J., Burrows, S. M., Hoose, C., Safatov, A. S., Buryak, G., Fröhlich-Nowoisky, J., Elbert, W., Andreae, M. O., Pöschl, U., and Jaenicke, R.: Primary biological aerosol particles in the atmosphere: A review, Tellus B, 64, 15598, https://doi.org/10.3402/tellusb.v64i0.15598, 2012.

Ehlert, K., Piepenbring, M., and Kollar, A.: Ascospore release in apple scab underlies infrared sensation, Fungal Biol., 121, 10541062, https://doi.org/10.1016/j.funbio.2017.09.001, 2017.

Elbert, W., Taylor, P. E., Andreae, M. O., and Pöschl, U.: Contribution of fungi to primary biogenic aerosols in the atmosphere: wet and dry discharged spores, carbohydrates, and inorganic ions, Atmos. Chem. Phys., 7, 4569-4588, https://doi.org/10.5194/acp-74569-2007, 2007.

Elbert, W., Weber, B., Burrows, S., Steinkamp, J., Büdel, B., Andreae, M. O., and Pöschl, U.: Contribution of cryptogamic covers to the global cycles of carbon and nitrogen, Nat. Geosci., 5, 459-462, https://doi.org/10.1038/ngeo1486, 2012.

Fernando, W. G. D., Miller, J. D., Seaman, W. L., Seifert, K., and Paulitz, T. C.: Daily and seasonal dynamics of airborne spores of Fusarium graminearum and other Fusarium species sampled over wheat plots, Can. J. Botany, 78, 497-505, 2000.

Fröhlich-Nowoisky, J., Kampf, C. J., Weber, B., Huffman, J. A., Pöhlker, C., Andreae, M. O., Lang-Yona, N., Burrows, S. M., Gunthe, S. S., Elbert, W., Su, H., Hoor, P., Thines, E., Hoffmann, T., Després, V. R., and Pöschl, U.: Bioaerosols in the Earth system: Climate, health, and ecosystem interactions, Atmos. Res., 182, 346-376, https://doi.org/10.1016/j.atmosres.2016.07.018, 2016.

Fürnkranz, M., Wanek, W., Richter, A., Abell, G., Rasche, F., and Sessitsch, A.: Nitrogen fixation by phyllosphere bacteria associated with higher plants and their colonizing epiphytes of a tropical lowland rainforest of Costa Rica, ISME J., 2, 561-570, https://doi.org/10.1038/ismej.2008.14, 2008.

Gadoury, D. M., Stensvand, A., and Seem, R. C.: Influence of Light, Relative Humidity, and Maturity of Populations on Discharge of Ascospores of Venturia inaequalis, Ecol. Popul. Biol., 88, 902909, 1998.

Gilbert, G. S. and Reynolds, D. R.: Nocturnal Fungi: Airborne Spores in the Canopy and Understory of a Tropical Rain Forest, Biotropica, 37, 462-464, 2005.

Gomes-Silva, A. C., Medeiros, P. S. de, Soares, A. M. da S., Sotao, H. M. P., Ryyarden, L., and Gibertoni, T. B.: Two new species of Rigidoporus (Agaricomycetes) from Brazil and new records from the Brazilian Amazonia, Phytotaxa, 156, 191-200, https://doi.org/10.11646/phytotaxa.156.4.1, 2014.

Gosselin, M. I., Rathnayake, C. M., Crawford, I., Pöhlker, C., Fröhlich-Nowoisky, J., Schmer, B., Després, V. R., Engling, G., Gallagher, M., Stone, E., Pöschl, U., and Huffman, J. 
A.: Fluorescent bioaerosol particle, molecular tracer, and fungal spore concentrations during dry and rainy periods in a semi-arid forest, Atmos. Chem. Phys., 16, 15165-15184, https://doi.org/10.5194/acp-16-15165-2016, 2016.

Graham, B., Guyon, P., Maenhaut, W., Taylor, P. E., Ebert, M., Matthias-Maser, S., Mayol-Bracero, O. L., Godoi, R. H. M., Artaxo, P., Meixner, F. X., Moura, M. A. L., Rocha, C. H. E. D., Grieken, R. Van, Glovsky, M. M., Flagan, R. C., and Andreae, M. O.: Composition and diurnal variability of the natural Amazonian aerosol, J. Geophys. Res., 108, 4765, https://doi.org/10.1029/2003JD004049, 2003.

Heald, C. L. and Spracklen, D. V.: Atmospheric budget of primary biological aerosol particles from fungal spores, Geophys. Res. Lett., 36, L09806, https://doi.org/10.1029/2009GL037493, 2009.

Hoose, C., Kristjánsson, J. E., and Burrows, S. M.: How important is biological ice nucleation in clouds on a global scale?, Environ. Res. Lett., 5, 1-7, https://doi.org/10.1088/17489326/5/2/024009, 2010.

Huffman, J. A., Sinha, B., Garland, R. M., Snee-Pollmann, A., Gunthe, S. S., Artaxo, P., Martin, S. T., Andreae, M. O., and Pöschl, U.: Size distributions and temporal variations of biological aerosol particles in the Amazon rainforest characterized by microscopy and real-time UV-APS fluorescence techniques during AMAZE-08, Atmos. Chem. Phys., 12, 11997-12019, https://doi.org/10.5194/acp-12-11997-2012, 2012.

Huffman, J. A., Prenni, A. J., DeMott, P. J., Pöhlker, C., Mason, R. H., Robinson, N. H., Fröhlich-Nowoisky, J., Tobo, Y., Després, V. R., Garcia, E., Gochis, D. J., Harris, E., MüllerGermann, I., Ruzene, C., Schmer, B., Sinha, B., Day, D. A., Andreae, M. O., Jimenez, J. L., Gallagher, M., Kreidenweis, S. M., Bertram, A. K., and Pöschl, U.: High concentrations of biological aerosol particles and ice nuclei during and after rain, Atmos. Chem. Phys., 13, 6151-6164, https://doi.org/10.5194/acp13-6151-2013, 2013.

Igbalajobi, O., Yu, Z., and Fischer, R.: Red- and Blue-Light Sensing in the plant pathogen alternaria alternata depends on Phytochrome and the White-Collar, MBio, 10, e00371-19, https://doi.org/10.1128/mBio.00371-19, 2019.

Ingold, C. T.: Spore Discharge in Land Plants, Clarendon Press, Oxford, 1939.

Ingold, C. T.: Water and spore discharge in ascomycetes and hymenomycetes, T. Brit. Mycol. Soc., 85, IN1, 575-583, https://doi.org/10.1016/s0007-1536(85)80250-3, 1985.

Jacobson, M. Z. and Streets, D. G.: Influence of future anthropogenic emissions on climate, natural emissions, and air quality, J. Geophys. Res., 114, D08118, https://doi.org/10.1029/2008JD011476, 2009.

Liang, L., Engling, G., He, K., Du, Z., Cheng, Y., and Duan, F.: Evaluation of fungal spore characteristics in Beijing, China, based on molecular tracer measurements, Environ. Pollut., 8, 014005, https://doi.org/10.1088/1748-9326/8/1/014005, 2013.

McWilliam, A.-L. C., Roberts, J. M., Cabral, O., Leitao, M. V. B. R., de Costa, A., Maitelli, G. T., and Zamparoni, C. A. G. P.: Leaf Area Index and Above-Ground Biomass of terra firme Rain Forest and Adjacent Clearings in Amazonia, Funct. Ecol., 7, 310 $317,1993$.

Melack, J. M. and Hess, L. L.: Remote Sensing of the Disribution and Extent of Wetlands in the Amazon Basin, in: Amazonian floodplain forest, edited by: Junk, W. J., Piedade, M. T. F., Flo- rian, W., Schöngart, J., and Parolin, P., Springer, Dordrecht, 210, 43-60, 2010.

Möhler, O., DeMott, P. J., Vali, G., and Levin, Z.: Microbiology and atmospheric processes: the role of biological particles in cloud physics, Biogeosciences, 4, 1059-1071, https://doi.org/10.5194/bg-4-1059-2007, 2007.

Moran-Zuloaga, D., Ditas, F., Walter, D., Saturno, J., Brito, J., Carbone, S., Chi, X., Hrabě de Angelis, I., Baars, H., Godoi, R. H. M., Heese, B., Holanda, B. A., Lavrič, J. V., Martin, S. T., Ming, J., Pöhlker, M. L., Ruckteschler, N., Su, H., Wang, Y., Wang, Q., Wang, Z., Weber, B., Wolff, S., Artaxo, P., Pöschl, U., Andreae, M. O., and Pöhlker, C.: Long-term study on coarse mode aerosols in the Amazon rain forest with the frequent intrusion of Saharan dust plumes, Atmos. Chem. Phys., 18, 10055-10088, https://doi.org/10.5194/acp-18-10055-2018, 2018.

Mueller, G. M., Bills, G. F., and Foster, M. S. (Eds.): Biodiversity of Fungi: Inventory and monitoring methods, Elsevier Academic Press, Burlington, US, 2004.

Neves, M. A., Baseia, I. G., Drechsler-Santos, R., and Goes-Neto, A. (Eds.): Guide to the common Fungi of the Semiarid Region of Brazil, TECC Editora, Florianópolis, Brazil, 2013.

Neves, T. T. de A. T. and Fisch, G.: The Daily Cycle of the Atmospheric Boundary Layer Heights over Pasture Site in Amazonia, American Journal of Environmental Engineering, 5, 39-44, https://doi.org/10.5923/s.ajee.201501.06, 2015.

Piepenbring, M.: Introduction to Mycology in the Tropics, The American Phytopathological Society, Minesota, USA, 2015.

Pöhlker, C., Wiedemann, K. T., Sinha, B., Shiraiwa, M., Gunthe, S. S., Smith, M., Su, H., Artaxo, P., Chen, Q., Cheng, Y., Elbert, W., Gilles, M. K., Kilcoyne, A. L. D., Moffet, R. C., Weigand, M., Martin, S. T., Pöschl, U., and Andreae, M. O.: Biogenic potassium salt particles as seeds for secondary organic aerosol in the Amazon, Science, 337, 1075-1078, https://doi.org/10.1126/science.1223264, 2012.

Pöhlker, C., Walter, D., Paulsen, H., Könemann, T., RodríguezCaballero, E., Moran-Zuloaga, D., Brito, J., Carbone, S., Degrendele, C., Després, V. R., Ditas, F., Holanda, B. A., Kaiser, J. W., Lammel, G., Lavrič, J. V., Ming, J., Pickersgill, D., Pöhlker, M. L., Praß, M., Löbs, N., Saturno, J., Sörgel, M., Wang, Q., Weber, B., Wolff, S., Artaxo, P., Pöschl, U., and Andreae, M. O.: Land cover and its transformation in the backward trajectory footprint region of the Amazon Tall Tower Observatory, Atmos. Chem. Phys., 19, 8425-8470, https://doi.org/10.5194/acp19-8425-2019, 2019.

Pöschl, U., Scot, T. M., Sinha, B., Chen, Q., Gunthe, S. S., Huffman, J. A., Borrmann, S., K., F. D., Garland, R. M., Helas, G., Jimenez, J. L., King, S. M., Manzi, A. O., Mihailov, E., Pauliquevis, T., Petters, M. D., Prenni, A. J., Roldin, P., Rose, D., Schneider, J., Su, H., Zorn, S. R., Artaxo, P., and Andreae, M. O.: Rainforest aerosols as biogenic nuclei of clouds and precipitation in the Amazon, Science, 329, 1513-1515, 2010.

Pringle, A., Patek, S. N., Fischer, M., Stolze, J., and Money, N. P.: The captured launch of a ballistospore, Mycologia, 97, 866-871, https://doi.org/10.3852/mycologia.97.4.866, 2005.

Pruß, S., Fetzner, R., Seither, K., Herr, A., Pfeiffer, E., Metzler, M., Lawrence, C. B., and Fischer, R.: Role of the Alternaria alternata Blue-Light Receptor LreA (White-Collar 1) in Spore Formation and Secondary Metabolism, Appl. Environ. Microb., 80, 2582 2591, https://doi.org/10.1128/aem.00327-14, 2014. 
Richards, P. W.: Notes on the Bryophyte Communities of Lowland Tropical Rain Forest, with Special Reference to Moraballi Creek, British Guiana, Vegetatio, 5, 319-328, 1954.

Sadyś, M., Kaczmarek, J., Grinn-Gofron, A., Rodinkova, V., Prikhodko, A., Bilous, E., Strzelczak, A., Herbert, R. J., and Jedryczka, M.: Dew point temperature affects ascospore release of allergenic genus Leptosphaeria, Int. J. Biometeorol., 62, 979990, https://doi.org/10.1007/s00484-018-1500-z, 2018.

Šantl-Temkiv, T., Sikoparija, B., Maki, T., Carotenuto, F., Amato, P., Yao, M., Morris, C. E., Schnell, R., Jaenicke, R., Pöhlker, C., Demott, P. J., Hill, T. C. J., and Huffman, J. A.: Bioaerosol field measurements: Challenges and perspectives in outdoor studies, Aerosol Sci. Tech., 1-27, https://doi.org/10.1080/02786826.2019.1676395, online first, 2019.

Saturno, J., Holanda, B. A., Pöhlker, C., Ditas, F., Wang, Q., Moran-Zuloaga, D., Brito, J., Carbone, S., Cheng, Y., Chi, X., Ditas, J., Hoffmann, T., Hrabe de Angelis, I., Könemann, T., Lavrič, J. V., Ma, N., Ming, J., Paulsen, H., Pöhlker, M. L., Rizzo, L. V., Schlag, P., Su, H., Walter, D., Wolff, S., Zhang, Y., Artaxo, P., Pöschl, U., and Andreae, M. O.: Black and brown carbon over central Amazonia: long-term aerosol measurements at the ATTO site, Atmos. Chem. Phys., 18, 1281712843, https://doi.org/10.5194/acp-18-12817-2018, 2018.

Schumacher, C. J., Pöhlker, C., Aalto, P., Hiltunen, V., Petäjä, T., Kulmala, M., Pöschl, U., and Huffman, J. A.: Seasonal cycles of fluorescent biological aerosol particles in boreal and semi-arid forests of Finland and Colorado, Atmos. Chem. Phys., 13, 11987-12001, https://doi.org/10.5194/acp-13-11987-2013, 2013.

Sesartic, A., Lohmann, U., and Storelvmo, T.: Modelling the impact of fungal spore ice nuclei on clouds and precipitation, Environ. Res. Lett., 8, 014029, https://doi.org/10.1088/17489326/8/1/014029, 2013.

Simoneit, B. R. T.: Organic matter in eolian dusts over the atlantic ocean, Mar. Chem., 5, 443-464, 1977.

Simoneit, B. R. T.: Organic Matter of the Troposphere-V: Application of Molecular Marker Analysis to Biogenic Emissions into the Troposphere for Source Reconciliations, J. Atmos. Chem., 8, 251-275, 1989.

Simoneit, B. R. T., Cardoso, J. N., and Robinson, N.: An assessment of the origin and composition of higher molecular weight organic matter in aerosols over Amazonia, Chemosphere, 21, 12851301, https://doi.org/10.1016/0045-6535(90)90145-J, 1990.

ter Steege, H., Pitman, N. C. A., Sabatier, D., Baraloto, C., Salomão, R. P., Guevara, J. E., Phillips, O. L., Castilho, C. V., Magnusson, W. E., Molino, J. F., Monteagudo, A., Vargas, P. N., Montero, J. C., Feldpausch, T. R., Coronado, E. N. H., Killeen, T. J., Mostacedo, B., Vasquez, R., Assis, R. L., Terborgh, J., Wittmann, F., Andrade, A., Laurance, W. F., Laurance, S. G. W., Marimon, B. S., Marimon, B. H., Vieira, I. C. G., Amaral, I. L., Brienen, R., Castellanos, H., López, D. C., Duivenvoorden, J. F., Mogollón, H. F., Matos, F. D. D. A., Dávila, N., García-Villacorta, R., Diaz, P. R. S., Costa, F., Emilio, T., Levis, C., Schietti, J., Souza, P., Alonso, A., Dallmeier, F., Montoya, A. J. D., Piedade, M. T. F., Araujo-Murakami, A., Arroyo, L., Gribel, R., Fine, P. V. A., Peres, C. A., Toledo, M., Aymard C., G. A., Baker, T. R., Cerón, C., Engel, J., Henkel, T. W., Maas, P., Petronelli, P., Stropp, J., Zartman, C. E., Daly, D., Neill, D.,
Silveira, M., Paredes, M. R., Chave, J., Lima Filho, D. D. A., Jørgensen, P. M., Fuentes, A., Schöngart, J., Valverde, F. C., Di Fiore, A., Jimenez, E. M., Mora, M. C. P., Phillips, J. F., Rivas, G., Van Andel, T. R., Von Hildebrand, P., Hoffman, B., Zent, E. L., Malhi, Y., Prieto, A., Rudas, A., Ruschell, A. R., Silva, N., Vos, V., Zent, S., Oliveira, A. A., Schutz, A. C., Gonzales, T., Nascimento, M. T., Ramirez-Angulo, H., Sierra, R., Tirado, M., Medina, M. N. U., Van Der Heijden, G., Vela, C. I. A., Torre, E. V., Vriesendorp, C., Wang, O., Young, K. R., Baider, C., Balslev, H., Ferreira, C., Mesones, I., Torres-Lezama, A., Urrego Giraldo, L. E., Zagt, R., Alexiades, M. N., Hernandez, L., HuamantupaChuquimaco, I., Milliken, W., Palacios Cuenca, W., Pauletto, D., Valderrama Sandoval, E., Valenzuela Gamarra, L., Dexter, K. G., Feeley, K., Lopez-Gonzalez, G., and Silman, M. R.: Hyperdominance in the Amazonian tree flora, Science, 342, 1243092, https://doi.org/10.1126/science.1243092, 2013.

Stensvand, A., Amundsen, T., Semb, L., Gadoury, D. M., and Seem, R. C.: Discharge and Dissemination of Ascospores by Venturia inaequalis During Dew, Plant Dis., 82, 761-764, 1998.

Webster, J. and Weber, R. (Eds.): Introduction to Fungi, Cambridge University Press, Cambridge, UK, 2007.

Whitehead, J. D., Darbyshire, E., Brito, J., Barbosa, H. M. J., Crawford, I., Stern, R., Gallagher, M. W., Kaye, P. H., Allan, J. D., Coe, H., Artaxo, P., and McFiggans, G.: Biogenic cloud nuclei in the central Amazon during the transition from wet to dry season, Atmos. Chem. Phys., 16, 9727-9743, https://doi.org/10.5194/acp-16-9727-2016, 2016.

Womack, A. M., Artaxo, P. E., Ishida, F. Y., Mueller, R. C., Saleska, S. R., Wiedemann, K. T., Bohannan, B. J. M., and Green, J. L.: Characterization of active and total fungal communities in the atmosphere over the Amazon rainforest, Biogeosciences, 12, 6337-6349, https://doi.org/10.5194/bg-12-6337-2015, 2015.

Yáñez-Serrano, A. M., Nölscher, A. C., Williams, J., Wolff, S., Alves, E., Martins, G. A., Bourtsoukidis, E., Brito, J., Jardine, K., Artaxo, P., and Kesselmeier, J.: Diel and seasonal changes of biogenic volatile organic compounds within and above an Amazonian rainforest, Atmos. Chem. Phys., 15, 3359-3378, https://doi.org/10.5194/acp-15-3359-2015, 2015.

Zhang, T., Engling, G., Chan, C., Zhang, Y.-N., Zhang, Z.-S., Lin, M., Sang, X.-F., Li, Y. D., and Li, Y.-S.: Contribution of fungal spores to particulate matter in a tropical rainforest, Environ. Res. Lett., 5, 024010, https://doi.org/10.1088/1748-9326/5/2/024010, 2010. 